\title{
MALAYAN FISHERIES INVESTIGATIONS
}

\begin{abstract}
$T$ HE tragic story of the Singapore Regional Fisheries Research Station, from its inception in January 1954 until it closed in March 1957, has been vividly told by Dr. Ommanney in his book Eastern Windows. The scientific results of this brief venture are recorded in three Colonial Office Fishery Publications recently published*. The laboratory was ready for occupation only towards the end of the second year and was never finished. Until the arrival of the research launch in June 1954, Mr. Hall was unable to work on fishes and studied some biological aspects of a Singapore commercial prawn pond. Later the work on Penaeids was extended to the Singapore Strait and samples taken by local fishing gears were obtained from Alor Star, Penang and Malacca. When the F.R.V. Manihine eventually arrived, ichthyological studies took precedence over other work, but incidental catches of prawns from offshore waters in the Malacca Strait and the South China Sea were examined at a later date.

Penaeid prawns are of great economic importance throughout the Indo-West-Pacific, in the Mediterranean, in the Gulf of Mexico (where they are called 'shrimps') and elsewhere. Large frozen tails are now sold in London as 'finest pacific prawns' (uncooked), or when Dublin Bay prawns are unobtainable, as 'scampi' (cooked). The seas around Malaya have an exceedingly rich fauna; Mr. Hall's total of 53 species may be compared with totals of 39 from Japan, 27 from India or Australia and 19 from South Africa. Since reproductive and other habits vary, not only with the species but also with climate, topography and other ecological factors, detailed regional surveys of the taxonomy and biology of Penaeids are essential. An excellent example of the effect of climate on spawning behaviour is provided by the prawns around Singapore and Penang Islands. At Singapore the year is almost equally divided between the south-west and the north-east monsoons and twice annually the westerly flow of the water through the Strait is slowed down and possibly reversed. Species of Penaeus breed primarily during the

* Colonial Office Fishery Publications. No. 16, 1961: A Quantitative and Qualitative Study of Some Indo-West Pacific Plankton. By J. H. Wickstead. Pp. $200+62$ figs. +42 tables. 55 s. net. No. 17, 1962: Observations on the Taxonomy and Biology of Some Indo-West-Pacific Penaeidae (Crustacea, Decapoda). By D. N. F. Hall. Pp. 229+125 figs. +15 tables. 92s. net No. 18, 1961 (1962). Malayan Offshore Trawling Grounds. The Experimenta and Exploratory Fishing Cruises of the F.R.V. Manihine in Malayan and Singapore Strait. By F.D. Ommanney. Pp. $95+$ figs., charts, tables. $36 s$. net. (London: H.M.S.O.)
\end{abstract}

north-east monsoon, February-April; most of the other species have two peaks of reproductive activity coinciding with the inter-monsoon variable periods, May-July and October-December. Each peak is produced by a distinct breeding population and the phenomenon has been termed "equatorial alteration of populations". Thus an abundance of fry enters the ponds thrice yearly and those that survive to adolescence are ready to migrate to the coastal or offshore spawning grounds at different times. Five possible spawning areas are predicted for the Singapore region. Penang, on the other hand, is under the influence of the south-west monsoon for most of the year and only once is the northerly flow of water past the Island slowed down or possibly reversed; correlated with this all the prawn species appear to have a single peak of maximum breeding activity in September. Until a detailed survey of this region can be undertaken, the probable offshore spawning loci cannot be predicted and confirmed. The great fixed stake-nets must therefore continue to operate although they catch many immature prawns of low commercial value. One possible unexploited source of the large Penaeus penicillatus is the area around and to the north of the Sungei Rokan Estuary.

It is fortunate that Mr. Hall could not adhere strictly to his original plan of publishing the taxonomic results elsewhere "to allow the biological results to be published without further encumbrance". The value of the monograph is greatly enhanced by the addition of a revised key to the determination of the genera and species of Malayasian Penaeidae, illustrated by a large number of line drawings.

Since the inshore fisheries of the Archipelago were being operated to saturation point, the possibility of developing an offshore fishery in the waters of Malaya and Borneo had to be investigated. The Manihine operated for only eleven months and a very large area had to be explored. In addition to fishing trials with a variety of gears, hydrological and plankton surveys were made. The results obtained are recorded in the publications by Dr. Ommanney and Mr. Wickstead. This regional scientific investigation is of necessity incomplete; given a few more years the Research Station would have proved eminently worth while. Dr. Ommanney and his assistants are to be congratulated on having accomplished so much in the short time available.
IsABELLA GORDON

\section{HIGHER NATIONAL CERTIFICATES AND DIPLOMAS IN APPLIED BIOLOGY}

$\mathrm{T}$ HE Ministry of Education has recently issued fresh regulations for courses and examinations leading to Higher National Certificates and Diplomas in Applied Biology, commencing with the session 1963-64. They will be under the supervision of a Joint Committee on which representatives of the Ministry and the Institute of Biology sit. Under the scheme, colleges will be required to submit to the Committee, for approval, details of the courses which they are prepared to offer; and it is expected that these will normally be of a part-time nature, extending over a period of not less than two years and covering a minimum of 480 hours spent on scientific work. In addition, it is assumed that a substantial allocation of the students' time will be devoted to general studies.

Each course will include three scientific subjects, of which biochemistry must be one; and it is suggested that while not compulsory, the physiological aspects of living matter, together with microbiology, will generally receive strong emphasis. Other subjeots which may gain approval include plant and animal physiology, applied entomology, genetics, parasitology, statistics and industrial administration, while for pharmacology special arrangements may be made. In planning and running courses of this nature it is expected that there should be active cooperation between the college staff, workers and executives in local industries, research institutes, universities and Government establishments; and in the examinations, provision can be made for studies of the application of biological principles and techniques in specified fields. A related objective is to introduco the students to the relevant biological literature. At all stages, regard will be paid to the use of good English. 
For entry to these courses, students will normally be required to possess a General Certificate of Education with passes at Advanced Level in one biological subject and one other science, to have completed a course in chemistry up to Advanced Level, and to have qualified at Ordinary Level in physies and mathematics and in the use of English. Students who already hold an Ordinary
Endorsed Certificate in Biology will also be accepted. Applications from others will be considered on their merits.

These regulations apply to England and Wales. Further information about them can be obtained from the Institute of Biology, 41 Queen's Gate, London, S.W.7, as well as from the respective offices of the Ministry.

\section{THE CZECHOSLOVAK SOCIETY OF ARTS AND SCIENCES IN AMERICA}

\begin{abstract}
$\mathrm{T}$ HE first congress of the Czechoslovak Society of Arts and Sciences in America, Inc., was held during April 20-22, 1962, at Statler-Hilton Hotel, Washington, D.C., and was attended by more than 200 scientists and scholars from all over the United States and Canada.

There were some 60 papers presented at these meetings, arranged in a two-day symposium based on the contributions of the Czechoslovak people to various fields of learning. The programme covered a wide variety of topies and included papers on science, medicine and technology; fine arts; literature and literary criticism; linguistics and Slavistics; law and economics; history and political science; sociology, theology and philosophy; and a special session was devoted to the accomplishments of Czechs and Slovaks abroad.

In the field of history of science the following papers were presented: "Jiři Matiegka and the Anthropometric Approach to the Study of Body Composition" (Josef Brožek, Lehigh University); "Purkinje Effect in the Evolution of Scientific Thought" (Karel Hujer, University of Chattanooga); "Five Centuries of Czech Geography, Exploration, and Cartography-Comments on Major Trends and Present Status" (Miloš Šebor, Tennessee Polytechnic Institute); "The Czechoslovak Contribution to the Change in Concept of Circulation of the Blood"' (Walter Redisch, New York University); "Augustine Herman, Bohemian" (M. Norma Svejda, Augustine Herman Czech American Historical Society); "Aleš Hrdlička, Pioneer American Physical Anthropologist" (T. Dale Stewart, United States National Museum);
\end{abstract}

"The Character of Czech Science: A. Contribution to the Sociology of Knowledge" (Otakar Machotka, Harpur College); "The Role of the Intelligentsia in the Development of the Czechoslovak Society" (Jan Hajda, the Johns Hopkins University); "Prokop Waldfogel of Prague and the XVth Century Printers in the Kingdom of Bohemia" (Jaroslov Némec, National Library of Medicine); "A Review of Contemporary Knowledge about Atherosclerosis" (O. J. Pollak, Dover Medical Research Center); "Speech Communication: Present Status and Salient Problems" (Ladislav Dolanský, North Eastern University): "The Symmetric Method, Natural Computational Method of Finite Metrix Games" (Josef V. Talacko, Marguette University).

Short summaries of all papers presented are available in the Abstracts (Washington and New York, 1962), which were published by the Society at the time of the First Congress. The papers are now being prepared for publication under the editorship of M. Rechcigl, jun., of the National Institutes of Health.

The following new officers of the Society were elected for the current term: President, Prof. René Wellek (Yale University): Secretary-General, Rudolf Sturm (Skidmore College).

Preparations are under way for the second congress of the Society, which will be held during September 11-12, 1964, at Columbia University, New York City. Further information concerning the Society and the second congress can be obtained from Dr. M. Rechcigl, jun., 1703 Mark Lane, Rockville, Md. M. Rechcigr, JuN.

\section{NEW LIGHT ON OLD EYES* \\ By R. A. WEALE \\ Department of Physiological Optics, Institute of Ophthalmology, University of London, Judd Street, W.C.I}

\begin{abstract}
T $\mathrm{N}$ one of Fick's writings ${ }^{1}$ there is a striking passage in which he discusses accommodation and its mechanism. There is no need, he said in 1879, "to discuss sundry theories of accommodation now that the problem has been solved in its entirety" (by Helmholtz" ${ }^{2}$. Fincham $^{3}$ showed in 1925 to what extent Holmholtz had solved the question in its entirety, and I think that a krief survey of the problem may enable us to relate it to presbyopia as a whole.

Briefly, Helmholtz stated that the natural shape of the lens is accommodated. It is allowed to assume this form when the eiliary muscle constricts. When the innervation to the muscle is abolishod, it dilates. increases its pull on the zonule, and this, in turn, pulls on the equatorial region of the lens. As a result the lens flattens (Fig. 1a). Accommodation is said to be relaxed. This

* Substance of a paper given before the Ophthalmological Section of the Royal Society of Medicine on October 11, 1962.
\end{abstract}

theory assumes the lens substance to be elastic, for otherwise removal of zonular restraint could not lead to the lens approximating to its accommodated shape. It will be recalled that, on extirpation, the lens radji of curvature are reduced even further, suggesting that even in full accommodation residual zonular tension exerts some control on the shape of the lens ${ }^{4}$.

Fincham ${ }^{3}$ showed that this theory cannot explain presbyopia, which is accounted for on the basis of Helmholtz's theory by postulating senile lenticular sclerosis. His criticism was based on several points of which I shall mention two. First, full accommodation requires an effort at all ages, and in presbyopio plus lenses are required for close work even though the near point may not lie beyond the normal reading distance. A variation of what used to be called the physiological amplitude of accommodation will scarcely account for this. Secondly, as Duane had shown, the cycloplegic action of homatro- 